conditions of this test, whereas the other histone fractions, protamine, dextran sulphate and DEAE-'Sephadex', a positively charged polysaccharide, all have little or no effect.

It is tempting to suggest that this is rolated to its specific function of finally repressing the DNA in the avian erythrocyte nucleus, but there is at present no evidence of its ability to penetrate cell and nuclear membranes.

This work was supported by grants to the Chester Beatty Research Institute (Institute of Cancer Research: Royal Cancer Hospital) from the Medical Research Council and the British Empire Cancer Campaign for Research.

F. W. Johns

Chester Beatty Research Institute

of Cancer Research,

Royal Cancer Hospital,

Fulham Road, London SW3.

lieceived May 19; revised June 15, 1970.

${ }^{1} \mathrm{~J}$ (h)n, E. W., Homeostatic Regulators (Ciba Foundation Symp.) (edit. by Wolstenholine, R. E. W., and Knight, J.), 128 (Churchill, London, 1969), 2 Johns, F. W., Biochem. J., 92, 55 (1964).

${ }^{3}$ Johns, E. W., Biochem, J., 105, 611 (1967).

4 Vidali, G., and Neelin, J. M., Eurcp. J. Biochem., 5, 330 (1968).

'Palau, J., and Butler, J. A. V., Biochem. J., 100, 779 (1966).

- Fambrough, D). M., and Bonner, J., Biochemistry, 5, 2563 (1966).

"Bloch, 1). P., Genetics Supplement, 61, 1 (1969).

${ }^{8}$ Hnilica, L. S., Experientia, 20, 13 (1964).

Dick, C, and Johns, E. W., Biochim. Biophys. Acta, 175, 414 (1969),

${ }^{10}$ Johns, E. W., and Jiggle, J. H., Europ. J. Biochem., 11, 445 (1969).

${ }_{11}$ Johns, E. W., Riochem. J., 104, 78 (1967).

\section{Gonadotrophin Inhibitory Properties of Pineal Extracts}

ExTracts of urine and pineal aro capable of inhibiting the activity of human chorionic gonadotrophin (HCG) in the mouse uterus assay ${ }^{1,2}$. The failure to detect an inhibitor in urine from patients with sexual precocity due to pinealoma suggested that the pineal was the source of the urinary gonadotrophin inhibitor ${ }^{1}$. On the other hand, the presence of a gonadotrophin inhibitor in the pincal or in urine has been doubted ${ }^{3,4}$ or the effects of the latter have been ascribed to the toxicity of the extracts used $^{5}$. The gonadotrophin inhibitory properties of pineal extracts clearly warrant further investigation and I roport here the effects of a pineal extract on gonadotrophin responses in the mouse uterus assay.

A protein-free extract of bovine pineal glands was prepared by the trichloroacetic acid method of Reiss et al. ${ }^{6}$. The gonadotrophin inhibitory properties of this extract were evaluated in mice as previously described? The animals (20-22 days old) were from an inbred colony and initially weighed 8-11 g. Treatment groups consisted of eight to ten animals and all injections wero given subcutaneously in aqueous solution, except oestrone, which was administered in olive oil. HCG and pregnant mares' serum gonadotrophin (PMS) were obtained from Organon Laboratories ('Pregnyl' and 'Gestyl' respectively) while follicle-stimulating hormone (FSH) was supplied by Armour-Baldwin Laboratories ('FSH-P'). The total dose of $\mathrm{HCG}$ was $0.4 \mathrm{IU}$ and $5.0 \mathrm{IU}, \mathrm{PMS}, 0.5 \mathrm{IU}$ and 10.0 IU and that of FSH was equivalent to $400 \mu \mathrm{g}$ NIH-FSH-S1. Groups of mice were injected at different sites with HCG $(0.4 \mathrm{IU})$ and FSH (50 $\mu \mathrm{g}$ equivalents), and oestrone was given in a total dose of $0.3 \mu \mathrm{g}$. The animals were also given the equivalent of $1 \mathrm{~g}$ wet weight pineal but at a different site from the injections of gonadotrophins or oestrone. Controls for comparison with tho pineal series were given distilled water.

Treatment was given for 3 days using tho following volumes: $\mathrm{HCG}, \mathrm{PMS}$ and $\mathrm{FSH}, 0.4 \mathrm{ml}, 0.3 \mathrm{ml}$. and 0.3 ml.; HCG and FSH together, $0.2 \mathrm{ml}$. (of each), $0.15 \mathrm{ml}$. and $0.15 \mathrm{ml}$; oestrone, $0.1 \mathrm{ml}$. daily, and pineal extract or water, $0.2 \mathrm{ml}$. daily. On the fourth day, the mean body weight and uterine weights from the test groups were compared with those given gonadotrophins (or oestrone) and distilled water using the Student $t$ test.

The pineal extract inhibited the uterine weight response to 0.4 IU HCG although the effect of nestrone was not impaired (Table 1). These results confirm previous findings ${ }^{\mathrm{x}}$. In addition it was found that the effect of 0.5 IU PMS was suppressed by the treatment. The responses to larger doses of HCG and PMS $(5 \cdot 0$ IU and 10.0 IU respectively), FSH, and HCG $(0.4 \mathrm{IU})$ given with FSH were not affected by the pineal extract (Table 1).

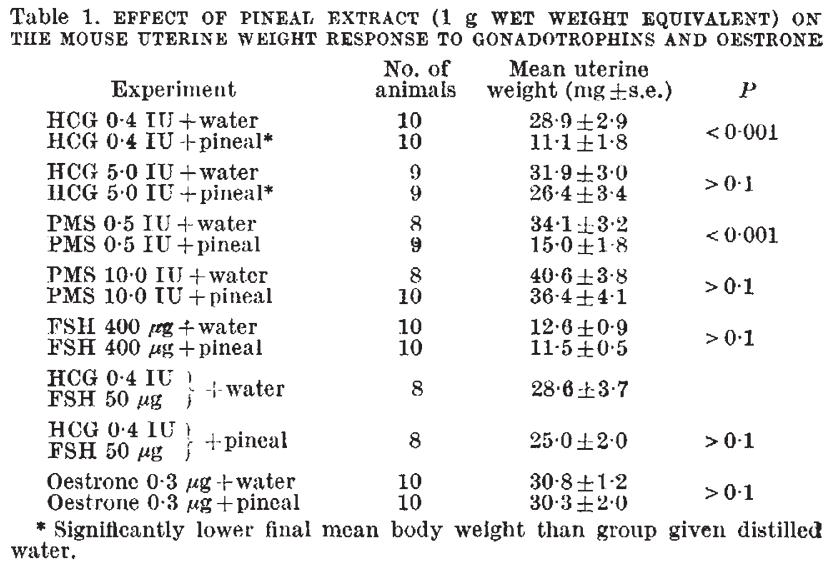

The results show that the effects of a pineal extract on gonadotrophin activity in the mouse uterus assay are identical to those obtained with urinary extracts? findings do not necessarily mean, however, that there is the same physiological substance in both urinary and pineal extracts. As well as with urinary extracts, identical results to those above have previously been obtained with such stressing procedures as starvation or carbon tetrachloride administration ${ }^{8}$ and it has been postulated that this affects endogenous gonadotrophin production rather than the exogenously administered hormone ${ }^{7,8}$. It is therefore possible for the effects of pineal and urinary extracts to be independent and caused by the toxicity of the injected material. The suppression of normal body weight gain in two groups of mice given pineal extract is indicative of the toxic nature of such extracts. Reports of increased adrenocortical activity and depressed liver function in $\operatorname{rats}^{6}$ and of a reduction in their spontaneous activity ${ }^{9}$ are also probably manifestations of the toxicity of pineal gland extracts. Furthermore, the use of purified, non-toxic pineal material may account for the failure of some workers to demonstrate inhibitory activity ${ }^{3}$.

I thank Mrs J. Sullivan for technical assistance. L. J. HIPKIN

Sub-department of Endocrino Pathology,

Liverpool Clinic,

Myrtle St.,

Liverpool 7.

Received Mayi11; revised July 17, 1970.

${ }^{1}$ Soffer, L. J., Fogel, M., and Rudavsky, A. Z., Acta Endocrinol., 48, 561 (1965).

¿ Yamashita, I., Irillman, J. C., and Reiss, M., J. Endocrinol., 33, 223 (1965).

${ }^{3}$ Schneider, H. P. G., Staemmler, H. J., Sachs, S. L., and Glöckner, C. Arch. (xynäk., 206, $72(1968)$.

Hahn, II. B., and Albert, A., J. Clin. Endocrinol., 25, 409 (1965).

'Rosenberg, E., Keller, P. J., Bulat, G., and Ferrechio, G. B., J, Clin. Endocrinol., 25, 1609 (1965).

- Reiss, M., Davis, R. H., Sideman, M. B., Mauer, I., and Plichta, E. S., J. Endocrinol., 27, 107 (1963).

'Hipkin, L. J., Acta Endocrinol., 59, 417 (1968).

${ }^{3}$ Hipkin, L. J., Endocrinology, 84, 482 (1969).

- Reiss, M., Davis, R. II., Sideman, M. B., and Plichta, E. S., J. Endocrinol., 28, $127(1963)$. 